\title{
Aboriginal stars of the pigskin
}

\author{
John Maynard
}

I wrote this article in early 1996 during my term as the Aboriginal History Stanner Fellow, Australian National University. I wanted to impress that although much had been written about the participation of Aboriginal sportsmen and women, particularly in boxing, football and athletics, there had been little researched or written regarding their involvement with horse-racing. This article is the result of research during that period. Sadly the depth of my research was restricted by the limit of my stay of only four months and that I was also researching the awakening Aboriginal political movement of the 1920s. In mid 1998 I received a grant from the Australian Institute of Aboriginal and Torres Strait Islander Studies to enable me to encompass a far more exhaustive study on the aspect of Aboriginal involvement with the 'Sport of Kings'.

My present project has allowed me the financial time and freedom to explore all of the avenues of research I could not encompass during my time as the Stanner Fellow. The project, as with the original article, was conceived with the idea of publishing another important missing chapter of Australian Aboriginal history: detailing the instance of Aborigines' horsemanship since colonisation before exploring their subsequent introduction to horseracing. An important aspect of this present study will be the dispelling of long held myths and misconception that there has only been minimal Aboriginal involvement with horseracing. Many journalists, sports writers, historians and academics have in the past failed to observe significant and continued Aboriginal association with horseracing. This is in no way meant to deride previous written histories. Many of these were general studies of Australian horseracing, that only gave at best brief mention of Aboriginal involvement, or biographies of Aboriginal sportsmen and women, where the researchers have had limited knowledge of horseracing that limited access to information and resources. These have been instrumental in forming an opinion of limited Aboriginal involvement. My present research will not only reveal the significant depth of Aboriginal involvement, where dozens of Aboriginal riders have been successful on metropolitan tracks capturing some of racing's greatest prizes, but also why many researchers have failed to observe the presence of Aboriginal riders. In that sense, this article is now a prelude to a much larger canvas.

Prior to the British invasion in 1788, there were no horses on the Australian continent. Governor Phillip had acquired a stallion, three mares and three yearlings at the Cape of Good Hope en route to Australia. In the space of twenty years 117 horses are recorded in the colony. ${ }^{1}$ The Aborigines first contact with horses were at once one of bewilderment and terror. Victorian Aborigines from around the Gippsland area indi- 
cated that they were under the belief that the noise of gunfire came from a horse's nostril. ${ }^{2}$ However, in a short time Aborigines shed their fears and displayed open curiosity and an appetite to learn how to ride the animal. Reynolds highlights instances of this, one early settler remarking that Aborigines had used sheets of bark as improvised saddles. $^{3}$ Another outback squatter was recorded in a Brisbane paper as saying "that the blacks not only killed the cattle and attacked stations but also stole the horses. ${ }^{4}$ Another instance highlighted the interest and level of experimentation used by Aborigines in their quest for knowledge and skills in horsemanship: 'In 1884 a police constable found a stockyard in the bush containing two horses which were regularly fed and ridden by local Aborigines'. ${ }^{5}$

As rural British settlement took its course Aborigines were hunted and hounded. In most areas they were a people without land and frequently denied even their most basic requisites: as the ability to fend and feed themselves had been stripped away. Pastoralists were now in control of vast areas. The Aborigines moved onto the farms and stations in search of work. Aboriginal men became the backbone of the pastoral industry as stockmen, trackers and general farm labourers. ${ }^{6}$ Women tended to fill domestic duties although many women also became accomplished stockriders. Once given the opportunity to ride a horse, Aborigines displayed an uncanny affinity and developed great skills as horsemen. One pioneer remarked in 1884 'I don't know what we pioneers should have done without the blacks for they can't be beat at looking after horses and cattle'. ${ }^{7}$ Another squatter wrote 'Above all horse riding enchanted them' and 'they are ambitious to learn to ride and do not mind a few falls in acquiring the art'.

Australia's first official horse race meeting was held in Sydney's Hyde Park in 1810. Officers of the 73rd regiment organised the three-day meeting. ${ }^{9}$ The Sydney Gazette heralded the coming meeting:

The races commence on Monday the 15 th October, and will continue until the Friday following with omission of the Tuesday and Thursday. The course has been completed at a very considerable expense and is esteemed a very fine one. Several handsome plates and other elegant presents, among which is a silver cup of 50 guineas value, given by the ladies of the colony, are to be contested for by the horses of subscribers to the race course; and a purse of 50 guineas will be given by the magistrates of the colony, free for all horses to be run on the last day. ${ }^{18}$

It was only natural, given their opportunity on horseback, that some Aboriginal men would venture now into the realms of horseracing at first acting as strappers and stable boys.

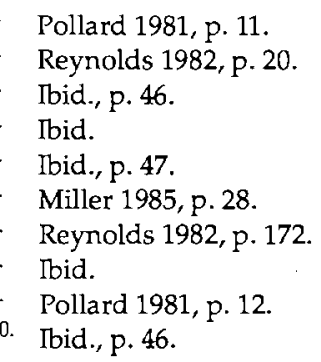




\section{Peter St Albans}

The first officially recorded instance of an Aboriginal winning a major race was Peter St Albans in 1876. ${ }^{11}$ Mystery and intrigue surrounds St Albans' background. However it is known that he commenced working as a stable boy for James Wilson at St Albans Stud, situated on the Barwon river about three miles from Geelong. The year 1876 also proved Briseis to be one of the greatest mares ever sired in Australia. The 'wonder filly' burst onto the Australian racing scene in the autumn of that year like a comet and raced into immortality. ${ }^{12}$ James Wilson bred Briseis at St Albans by mating Tim Whiffler and Musidora. She was one of the first foals delivered at St Albans. She had her first race start at the Melbourne Cup meeting of 1875 where she carried 5 pounds $(2.25 \mathrm{~kg}$ ) overweight, at 4 stone 9 pounds, into third place in the All Aged Stakes. ${ }^{13}$ In those early two-year-old races she showed promise but could not break through for a win. In fact by the time Wilson took her north to Sydney in the autumn of 1876 she was still a maiden. Peter St Albans was only twelve years old when he was given his first chance on Briseis in the 1876 Australian Jockey Club Doncaster Handicap. ${ }^{14}$ The leading rider of the stable, Tom Hales, could not make the weight to ride Briseis in the Doncaster. Hales, much to his credit, was instrumental in pointing out to owner and trainer James Wilson that young strapper St Albans showed great ability as a horsemen and had a special bond with the filly. Hales asserted to Wilson 'you had better give the ride to young Peter'. ${ }^{15}$ Many ardent racegoers questioned Wilson's intentions in running Briseis, then only a two year old, in the demanding Doncaster, a race for all comers over a mile, ridden by an inexperienced twelve year old boy. Briseis and Peter St Albans rewarded Wilson's confidence by winning the Doncaster in 1 minute and 45.5 seconds, carrying 5 stones 7 pounds $(34.6 \mathrm{~kg})$, and clipping a half second off the race record. ${ }^{16}$ It was recorded that the Randwick crowd 'cheered and celebrated for little St Albans and the filly' ${ }^{17}$ Three days after her Doncaster victory Briseis blitzed the opposition in the six furlongs Flying Handicap. The following day the paired Briseis and Peter St Albans, carrying 5 stones and 11 pounds $(36.4 \mathrm{~kg}$ ), took out the All Aged Stakes over one mile defeating, at weight for age, Kingsborough, one of New South Wales best horses. ${ }^{18}$

Seven months later in the spring of 1876 a similar story unfolded at the Melbourne Cup carnival. Stable jockey Tom Hales rode Briseis to victory in the Victoria Race Club Derby on the Saturday in a record time of 2 minutes 43.25 seconds. This was the second fastest time ever recorded anywhere in the world. ${ }^{19}$ It was a different story for the following Tuesday's Melboume Cup. Briseis was allotted 6 stones 4 pounds ( $39.6 \mathrm{~kg}$ ) and Hales again could not make the weight. James Wilson this time needed no prompting and had no hesitation in handing the reins to the now thirteen year old Peter St Albans. ${ }^{20}$ Another source states that rumoured skulduggery led to Wilson giving the

11. Pollard 1988, p. 2.

12. Ibid., p. 123.

13. Ahern 1982, p. 40.

14. Pollard 1988, p. 2.

15. Ibid.

16. Ibid., p. 123.

17. Tatz 1995, p. 247.

18. Ibid.

19. Cavanough 1983, p. 41. 
mount to Peter St Albans.'[S]tories of a jockies' ring at the time-stories that were subject of official inquiry and ultimate action' were circulating. ${ }^{21}$ One humorous highlight of St Albans' Melbourne Cup ride was that he had to wag school. On Cup day the principal of the Geelong school he attended was asking other students where young Peter St Albans was! $!^{22}$ His classmates informed the disbelieving principal that Peter was 'down in Melbourne winning the Cup'. ${ }^{23}$ Ahern asserts ' $[w]$ hatever the truth of his real age, it is on record that one P St Albans was absent from the Connewarre Public School on 7 November 1876, Melbourne Cup day'. ${ }^{24}$

The Melbourne Cup of 1876 was one of high drama, intrigue and tragedy that can hardly be matched in its entire history. On Saturday 9 September, two months before the Cup, the SS City of Melbourne sailed from Sydney to Melbourne. Amongst her cargo were eleven racehorses, some of the most valuable thoroughbreds in the country, in the charge of trainer Joe Morrison. They included Nemesis, the winner of the Australian Jockey Club Metropolitan and favourite for the Melbourne Cup; two other well fancied horses, Burgundy and Sovereign; and Robin Hood, also highly fancied in Cup markets. He was regarded by many as the best horse in Australia after his wins in the 1875 Victoria Race Club Derby, Royal Park Stakes, Produce Stakes and the Australian Jockey Club St. Leger. On the Sunday morning the ship ran into a savage storm. Joe Morrison beseeched the skipper of the ship, Captain Paddle, to either take shelter in nearby Jervis Bay or return to Sydney as the high seas were endangering the lives of the valuable animals under his care. Captain Paddle refused to heed Morrison's advice and placed the ship and his cargo in great peril. Just after passing Cape St George the storm intensified to hurricane force. The ship was hit by a number of heavy waves; the wheel was smashed and the binnacle washed overboard. Chaos followed. The horses were panic stricken. Seven of them, including Nemesis, were washed onto the deck and killed. Robin Hood lost his footing and was trampled under foot by the other horses and despite all the efforts of Morrison he too died. Nine horses perished. The ship limped back to Sydney. One of the two surviving horses, Chrysolite, a colt was so sore he had to be carried ashore.

The disaster had repercussions for the upcoming Melbourne Cup. With so many of the top fancies now out of the running betting on the big race was paralysed. One macabre incident, highlighting the high corruption and violence of this period in Australian racing, ensued from the tragic loss of so much valuable horseflesh. The bookmakers jestingly presented a purse to Captain Paddle, to the dismay and anger of the public, as a token of their appreciation for the part he played in the death of the horses. He had saved them many thousands of pounds in bets already laid on the horses which perished! ${ }^{25}$ Yet the loss of all of these horses does not detract from the merit of Briseis's and Peter St Albans' win in the Melbourne Cup.

20. Pollard 1988, p. 124.

21. Ahern 1982, p. 42.

22. Pollard 1988, p. 2.

23. Hickie 1986, p. 162.

24. Ahern 1982, p. 42.

25. Cavanough 1983, pp. 38-40. 
Before a crowd of 75,000 people, starting at 7 to 1 , Briseis comfortably won the Cup by one and a half lengths in the time of 3 minutes and 36.5 seconds to become the first filly or mare to win the event. There were 33 runners in the Cup, the biggest field up to that time. Briseis and Peter St Albans got away to a good start and were always handy to the leaders before the young jockey made his move at the distance. Briseis drew alongside Sybil and under strong riding proved too good over the concluding stages of the race. ${ }^{26}$ The Australasian recorded Peter's ride: 'The boy who rejoices in the name of St Albans-which, we presume, is merely his nom de course-rode splendidly, sitting down and driving Briseis home in a manner that would have reflected credit upon Hales'. ${ }^{27}$ Another writer of the period, 'Augur', commenting on Peter St Albans' riding ability, wrote: 'as a lad St Albans was a more accomplished artist than three fourths of the adults' adding 'Mr. Wilson possesses a treasure in the lad he has named after his establishment, the youngster being a capital second edition of Mr. Wilson's eldest son, James. ${ }^{28}$ Augur's comments 'suggest very clearly that he was the illegitimate child of either Wilson Sr or his son James'. ${ }^{29}$ When Wilson was 'chided after the race by friends who had not had the same confidence as Mr. Wilson in young Peter St Albans' he replied: 'You did not know as much as I did. The boy has ridden her in all her work. She goes well for him, as you know now. ${ }^{30}$ Such was the strength of Briseis's Melbourne Cup win that two days later she frightened off the opposition in the Victoria Racing Club Oaks. Only two horses opposed Briseis in the Victoria Racing Club Oaks. Briseis concluded her remarkable sequence by winning the Oaks with Tommy Hales in the saddle. Incredibly Briseis was again saddled up on the Saturday, the final day of the carnival, in the Mares Produce Stakes for three year olds. Her winning run had ended. A tired and jaded Briseis battled on into second place beaten by Pride of the Hills and one and a half lengths. ${ }^{31}$ Briseis never won another race and was retired to stud. Tragedy struck when she was about to be served by King of the Ring. She took fright when placed in hobbles and reared backwards and fractured her skull. Her death was a great loss to the Australian breeding industry. ${ }^{32}$

Peter St Albans came, by dreadful bad luck, within a short half head of winning back to back Melbourne Cups. The 1877 Melbourne Cup is best remembered as one of the great race's most celebrated attempts to clean up the country's bookmakers. It became known as the 'Savanaka coup'. James Wilson combined great horsemanship and training with shrewdness and an unrivalled ability to prepare a plunge on the bookmaking fraternity. One of the owners of horses Wilson trained was Herbert Power. He was a member of the original committee of 12 elected from the 25 original foundation members of the Victoria Racing Club when it officially came into existence on 9 March 1864. Power was a high profile owner starved of racetrack success. He had owned the 4 to 1 favourite Feu d'Artifice which had finished a disappointing fifteenth behind Briseis in the 1876 Melbourne Cup. ${ }^{33}$ He exchanged Feu d'Artifice with promi-

26. Pollard 1988, p. 2.

27. Freedman 1990, p. 303.

28. Tatz 1995, p. 247.

29. Ibid., p. 248.

30. Ahern 1982, p. 42.

31. Freedman 1990, p. 303.

32. Pollard 1988, p. 124. 
nent Bathurst breeder George Lee for a grey two year old from his stud at Leeholme. The colt was named Savanaka. He was a full brother to Kingsborough, one of the nation's top horses which had won the Australian Jockey Club's Derby, St Leger, Champagne Stakes and Sires Produce Stakes and the Victoria Racing Club's Melbourne Stakes. ${ }^{34}$ Savanaka was entered in four two year old races. His introduction to racing was in the Maribyrnong Plate where he was unplaced. In his second start, he won the six furlong $(1.2 \mathrm{~km})$ Flying Stakes. In winning he defeated many top gallopers including Pride of the Hills, Sultan, Tocal, Rapidity and Salisbury. On the strength of that one two year old sprint victory Wilson felt he had a certain Melbourne Cup winner. Wilson convinced Savanaka's owner, Power, of his belief that they had a certainty and they must not risk running him again for fear that the horse's true ability would be revealed. They had no hesitation in scratching the two year old from his other engagements. The horse was sent back to St Albans stud where he was quickly forgotten by the racing public. ${ }^{35}$

Thus commenced twelve months of careful planning for the ultimate racing prize, the Melbourne Cup. Behind the locked gates at St Albans Wilson set in motion one of the biggest betting plunges ever instigated. Wilson and Power hoped that, with no real form to access, the handicapper would allot the horse a light weight to carry. When the weights for the cup were released, the following year Wilson and Power had achieved their first objective. Savanaka was given a mere 6 stones 2 pounds $(41 \mathrm{~kg})$. 'Only four horses had received less weight and Pride of Hills, one of those beaten in the Flying Stakes, had been given 9 stones $(57 \mathrm{~kg}) .{ }^{36}$ The second stage was to get the money on. What followed was 'the most sensational week's betting known in Australia up to that time' ${ }^{37}$ In one day alone Savanaka was backed to win over $£ 40,000(\$ 80,000)$. The average wage at the time was less than $£ 2(\$ 4)$ a week. Using the average wage in 1997 as a conversion rate it is equivalent to $\$ 12$ million! ${ }^{38}$ The racing public's imagination was set alight. Nothing like the magnitude of this betting had ever been witnessed, all on a horse which had only two starts and never been further than six furlongs $(1.2 \mathrm{~km})$. Adding spice to the occasion Chester, a horse trained by Melbourne Cup winning maestro Ettienne de Mestre, was also receiving heavy support. He had won the Australian Jockey Club Champagne Stakes and Sires Produce and ran, what many thought, was an unlucky second in the Australian Jockey Club Derby before heading south to win the Victoria Racing Club Derby. After his Victoria Racing Club Derby victory his owner the Hon James White, Sydney's most successful owner, instructed his betting commissioner, a Septimus Stephens, to place a bet with leading bookmaker Joe Thompson of $£ 10,000$ ( $\$ 20,000)$ to $£ 1,000(\$ 2,000)$. Most reports from the period state that the bet was only taken by Thompson because of his belief that Savanaka was a certainty and all of his money was behind the avalanche on that horse. The third stage in the coup was ensuring that Savanaka was up to the task of winning the race. In this he fully vindicated his trainer's early confidence. In a private trial at St Albans he ran the Melbourne Cup distance of two miles in 3 minutes 33 seconds an incredible three seconds faster than the

\footnotetext{
33. Gadfly Media 1996, p. 78.

34. Hickie 1986, p. 159.

35. Ibid., p. 160.

36. Ibid.

37. Cavanough 1978, p. 43.

38. Gadfly Media 1996, p. 78.
} 
race record set by Don Juan. Any doubts held by owner Power, trainer Wilson or plunge organiser Thompson were dispelled. ${ }^{39}$

Descriptions of the scene at Flemington convey the excitement and drama of the day 76,000 people packed the course. Some 37,000 alone came by train. The crowd was described as 'altogether too dense' and even the large grandstand, known as Bagot's cowshed, was left with hardly enough room to move in with many people injured in the crush. Then the rain came. Torrential rain fell. '[T]he grounds became a quagmire, squelching beneath thousands of trampling feet' ${ }^{40}$ Jockeys were compelled to wear overcoats during the parades in the enclosure. ${ }^{41}$ The race itself was full of excitement. The start heralded the drama that followed. When the flag fell two runners, Robinson Crusoe and Amendment, were facing the wrong way. In turning too quickly they collided, losing many lengths in the process. From the jump the 100 to 1 bolter, Fisherman, set up a blistering pace. It was still leading when the field passed the abattoirs. Savanaka racing midfield was described as 'bolting under the proverbial double wraps behind Waxy' ${ }^{42}$ Shortly after disaster struck. Fisherman began to tire and dropped back through the field sharply. Waxy was unable to dodge the tiring Fisherman and fell in front of Peter St Albans. He miraculously avoided Waxy but in the process had pulled Savanaka to a virtual stop. Conservative estimates from judges state that the incident cost Savanaka 10 to 20 lengths. ${ }^{43}$ Chester had avoided the scrimmage and came into the straight contesting the lead with Glenormiston. Shortly after Chester broke away. Vagabond moved to second. Over the final furlong Piggott, the jockey on Chester, relaxed thinking the race was won. Savanaka and Peter St Albans burst from the pack and charged down the outside, quickly overhauling Vagabond, and failing by a mere half head to grab Chester before the post. They finished some three lengths clear of Vagabond in a new Cup record of 3 minutes and 33.5 seconds. ${ }^{44}$ The following day's Brisbane's Courier Mail report stated: 'Savanaka came on at such a pace as has never been seen at the end of a two miles race in Victoria.' It went on to say: 'The performance of Savanaka fully justified the confidence reposed in him by the St Albans stable. Had he not been interfered with when Waxy fell he would have put Chester to his utmost, good colt as he is. $^{, 45}$ In another press report, the Argus wrote, 'Though he Savanaka only carried $6.12 \mathrm{St}$ Albans is such a mite of a jockey that he rode in a large saddle'. Ahern reinforcing that 'St Albans named for the stud where he worked and lived, was then only a boy, but apparently of more than average talent in the saddle ${ }^{\prime}{ }^{46}$

What of the major players in the Savanaka coup? The owner, Power, was horrified that the public, fuelled by an unsympathetic media, turned on the St Alban's connection venting their pleasure at the failure of the coup. The newspapers highlighted the stealth and level of secrecy behind the plunge. They attacked the way the ability of the horse was disguised, pointing out that the stables' links with the big bookmaker Thompson

\footnotetext{
39. Cavanough $1978, \mathrm{p} 44$.

40. Freedman 1990, p. 302.

41. Cavanough 1978 , p. 45.

42. Hickie $1986, \mathrm{p} 162$.

43. Tbid.

44. Cavanough 1978, p. 45.

45. Ahern 1982, p. 46.

46. Ibid.
} 
was responsible for the plan. Power was distraught by this attack against his integrity. One newspaper gloated: 'the public gained intense satisfaction that the clever party at St Albans whose deeds are dark and ways mysterious, got bowled over' and that the Cup had instead been won by the 'Hon. James White, a man who races for sport, not money. ${ }^{47}$ An incensed Power responded to this attack by asking if this was the case could someone explain to him why White was paid in excess of $£ 10,000$ for his winning bet with Thompson on the cup. Power had to wait another 22 years until he finally achieved his much sought after goal when his horse Merriwee won the 1899 Melbourne Cup. After this victory Power was heard to lament that great win as it was Merriwee was not in the same class as Savanaka. He proclaimed to all who would listen that Savanaka had been the greatest beaten Melbourne Cup certainty of all time. ${ }^{48}$

Thompson for his part continued on his way as the biggest betting bookmaker in the country. He returned to England at the end of his Australian career in 1889 with a fortune reputed to be in excess of $£ 100,000(\$ 200,000)$. He set up offices in Jermyn Street, London. The Australian press kept the public informed of his whereabouts and exploits. He was reported as involved in a brawl at a London boxing match. Another gave prominence to his attempt to start a racecourse in San Francisco. His betting plunges in partnership with Lily Langtry on Australian horses at Ascot also grabbed the headlines. Because of her intimate friendship with the Prince of Wales the beautiful Langtry had been the talk of England. Langtry and Thompson procured the Australian galloper Merman for $£ 1,500$. They recouped their money in an avalanche as Merman proceeded to win in succession the Cesarewitch, Goodwood Plate, Goodwood Cup and Ascot Gold Cup, picking up another $£ 100,000$ in wagers. In 1903 Thompson returned on a sentimental journey to Australia where he was feted by the upper echelons of Victorian society. By 1909 at the age of 71 he was still on his English bookie's stand, betting big and still loudly proclaiming he was the king of the ring. He took time off for a short holiday cruise to Madeira and died on board the ship from a sudden heart attack. ${ }^{49}$

Peter St Albans went on to taste other triumphs on the track, winning the 1880 Victoria Racing Club St Leger, 1880 Hobart Town Cup, 1881 Victoria Racing Club Sires Produce, Ascot Vale Stakes and Geelong Cup. St Albans may have had to carry the blame for the loss on Savanaka. All jockeys are aware that they are only as good as their last winner. Defeat, especially on a good thing where big money is involved, demands a scapegoat. Weight troubles probably enforced his early retirement. He became a horse trainer. His best horse was Forest King who ran second to G'naroo in the 1891 Caulfield Cup. He died in 1898 aged only 35 years. ${ }^{50}$ Jack Pollard, a doyen of Australian sports writing, states in his book Australian Horse Racing that Peter St Albans was Aboriginal. ${ }^{51}$ Many other writers have expressed the same opinion including Colin Tatz who states, in Black Diamonds, that in late 1995 he reached the conclusion that St Albans was undoubtedly Aboriginal. ${ }^{52}$ Most researchers including Pollard have expressed the opin-

47. Hickie 1986, p. 163.

48. Power is honoured today with the the Herbert Power Handicap run each year during the Caulfield Cup spring meeting. Ibid.

49. Ibid., p. 63.

50. Freedman 1990, p. 303.

51. Pollard 1988, p. 2 .

52. Tatz 1996, p. xv. 
ion that Peter St Albans was the illegitimate Aboriginal son of the stud owner James Wilson who paid a local labourer, Michael Bowden, and his wife to raise him. ${ }^{53}$ Robert Windmill, who published a history of racing in and around Geelong challenged these conclusions. He questions the view that St Albans was the illegitimate son of James Wilson and raised at his expense by Michael Bowden and his wife. However, Windmill's argument is put forth without evidence. Colin Tatz emphasised this point noting that Windmill's account reads as:

Some reports say the lad was an Aboriginal who was either abandoned as a baby at St Albans stud or arrived one day of his own accord. However, another theory, which has been passed down from generation to generation, is that the young boy was, in fact the illegitimate son of James Wilson. It is suggested that to camouflage this fact he was named after the stud and raised by labourer Michael Bowden and his wife ... moreover, paintings featuring Peter St Albans with some of the famous Wilson horses indicate that he could have been European. ${ }^{54}$

As Tatz so rightly points out this theory of St Albans being European amounts to only a question by Windmill. Tatz concludes that it is unlikely that St Albans was European:

Aborigines were very often, in fact most often, assigned the names of their 'owners', or the homesteads and stations where they worked. This never occurred among non-Aborigines. Every other jockey in the history of the race since 1861 has a real name. ${ }^{55}$

'Illegitimacy usually resulted in the child taking his or her mother's maiden name. If you'll excuse the pun, even if Wilson Sr or Wilson Jr was the stud, no one has raised the question of who Peter's mother was. ${ }^{56}$ The famous Fredrick Woodhouse painting which features Peter St Albans standing alongside Briseis with stable jockey Tom Hales in the saddle has done little to settle the dispute.

\section{Merv Maynard}

The modern era has produced talented Aboriginal riders like Lyall Appo, Glen Pickwick and Normie Rose to name just a few. The careers of two outstanding individuals are worth closer inspection. These two riders have some commonalties; they both rode in the Melbourne Cup, they have rubbed shoulders with royalty and they rode successfully on the international stage. They are Merv Maynard and Darby McCarthy.

Merv Maynard's father, Fred Maynard, was the founder of the Australian Aboriginal Progressive Association which formed in Sydney in 1924 and as such was a starting point and inspiration for organised political Aboriginal activism in this country. ${ }^{57}$ Fred Maynard's call for land-rights, citizenship and equal rights for Aboriginal people had him labelled by white authorities as an agitator and troublemaker. His group was constantly hounded and eventually harassed out of existence by the police acting for the Aboriginal Protection Board. ${ }^{58}$ Merv Maynard's recollections of his young years corrob-

\footnotetext{
53. Freedman,1990, p. 303.

54. Tatz 1995, p. 248.

55. Ibid.

56. Ibid.

57. Broome1982, p. 166.

58. Horner 1994, p. 27.
} 
orate those of his brother and sisters that threats were made against their father about the well-being of his children and that this was one of the reasons why such a high profile Aboriginal activist slipped from the limelight and, in some sense, into hiding. There may have been other reasons. It will never be known if Fred Maynard would have publicly kept up his campaign after being badly injured, one leg being broken in six places, while working a wharf labourer. This eventually led to the amputation of the leg and his death in $19466^{59}$

Merv Maynard began his working life washing bottles in a Lakemba chemist shop and, subsequently, as a delivery boy for the local Post Office. It looked at that stage as if the diminutive Maynard was in for a life of lumping mailbags. ${ }^{60}$ However, on visits to his aunts and uncles in Newcastle he began to haunt the surrounds of Broadmeadow racecourse where he was noticed by a leading trainer, Keith Tinson. This was hardly surprising. Young Merv looked a natural jockey in the making, weighing a mere 4 stones 8 pounds $(28.8 \mathrm{~kg}){ }^{61}$ Things looked bleak when young Merv had to return to his mother's Lakemba home. Yet he was not to be denied and spent much of his spare time with his face pressed against the tin fence of Canterbury racecourse watching the activities of trainers, jockeys and stablehands at early morning track gallops and race-meetings. ${ }^{62}$ One day Merv recognised a familiar face in Keith Tinson who had brought a couple of horses down to race at Canterbury. Merv called out to the trainer through a hole in the fence and Tinson obliged by asking attendants to let Merv onto the course where he spent the day tending to Tinson's horses. Tinson was impressed by the boy's keenness and energy. He offered the boy an apprenticeship as a jockey. With his mother's approval, Merv journeyed back to Newcastle with Tinson to begin his life in racing. ${ }^{63}$ Back in the late 40 's stable life was very hard. Seven days a week Merv's day would begin at $3 \mathrm{am}$. It was not until he was a full twelve months into his apprenticeship that he was allowed the time to attend a movie.

Merv could not have picked a more successful stable to join. Tinson had begun his training career back in 1928 and since that time his general knowledge of horses and breeding combined with the patience he would exercise with his animals had made him very successful. Tinson had learnt many points of horsemanship from his uncle Jack Hartigan, a former Maitland trainer. Tinson had won his first race with Bonnie Merv at Blandford, a private track owned by John Morrisey. He had tasted near continuous success from that humble beginning. He won 27 races with Gallant Queen including the Wallabadah Cup three years in succession. He trained at Rutherford up until 1941 when his team included the handy Salivar, Valack and Cup Day. Closure of the Maitland track forced him to relocate to Newcastle's Broadmeadow course. There he quickly established himself as the premier trainer in the north, heading the trainers list for the 1944, 1945, 1946 and 1949 seasons. He tasted big-time success in 1949 when Denali took out the Winter Handicap and the Australian Jockey Club Epsom handicap at Randwick ridden by Scobie Breasley. Denali was not the stable's only star, Tinson at this time had a

\footnotetext{
59. Goodall1997, p.168.

60. Goodwin 1953, p. 50.

61. Howe 1983, p. 5.

62. Tbid., p. 7.

63. Goodwin 1953 , p. 50.
} 


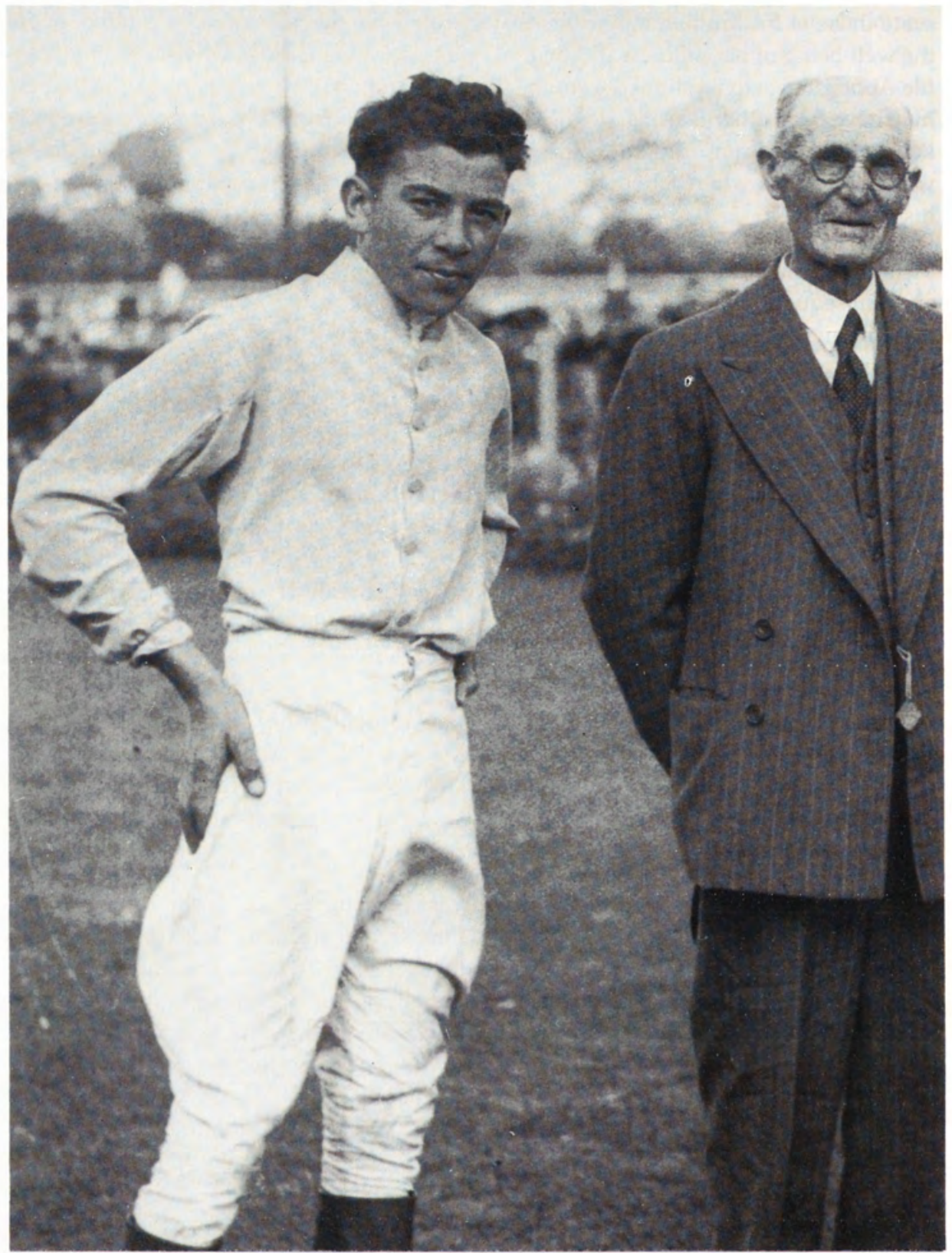

Aboriginal jockey Merv Maynard with trainer Norman Dewsbury after winning the first Queen's Cup on Salamanca at the Randwick racecourse, Sydney, in 1952. They were photographed while awating presentation to the Governor-General. 
very promising team which also included Warrah King and the ill fated Auburn River which was killed in a track accident after only two starts both of which he won by big margins. Auburn River's second metropolitan victory, with young Merv in the saddle, saw him blitz a field at Canterbury by 11 lengths. ${ }^{64}$

In his first season in 1948-49 Merv Maynard rode eight winners and quickly came to the notice of other trainers. His first success was at Wyong on 16 April 1949 when he won on the Tinson trained Paragon. The next season he rode ten winners including the winner of the Quirindi Cup. In a driving finish in that race his mount, Exalted, defeated the mount of Billy Cook. ${ }^{65}$ There were many great riders at this time, a period often referred to as the golden era of Australian jockeys. This was the case not just on city tracks either but in the country as well.

On reflection Merv pointed out that old Roy James was one who had a major influence on his own riding. James was a riding grandad when Merv's career began. Years later James was tragically killed in a track work fall at Canterbury. Stan Davidson was another influence. He hung up his saddle just after Merv started riding to take on training. Merv said: 'I never saw Davidson at his best but never the less you quickly realised what a great rider he must have been at his peak'. Merv also remarked that Hickey, Thompson and Waterson were all great local riders of the period:

Neil Waterson was a very good jockey, a brainy rider, pretty to watch, real neat and polished in the saddle and a thorough professional. Importantly they were all horsemen. Some people might criticise me for saying it but in that area comparisons with today are lacking, there are many great jockeys today. But great horsemen in this modern era are a very rare commodity. In my early days the further you went into the bush you struck them just as good, on the other side of the range were the likes of the Kelly's and Walmsley's. ${ }^{66}$

The 1950-51 season propelled Merv Maynard into national racing prominence. He rode Warrah King to victory in the Australian Jockey Club Shorts handicap at Randwick and also the Queensland Turf Club Lightning Handicap at Eagle Farm. In the Lightning Warrah King whipped a smart field winning by three lengths. ${ }^{67}$ The victory in the Lightning elevated Warrah King to favourite for the Doomben 10,000. If Warrah King had won the 10,000 ridden by the 18 year old apprentice it would have given the youthful Merv's career an enormous boost. Sadly it was not to be. Merv can still recall the voice of George Moore riding on his outside 'let him go son, let him go, it's your race' Merv replying 'not yet, not yet'. ${ }^{68}$ Third on the home turn and hooked out on straightening he looked the winner when, suddenly, Warrah King received a severe check from the eventual winner, Coniston, and crashed heavily to the turf. Merv Maynard had 26 horses go over and past him. Miraculously the young jockey walked away from the fall with nothing more than a broken big toe and smashed dreams.

More disappointment was to follow in September 1951 at Randwick before a crowd of 68,000 . Merv rode the 100 to 1 Queensland outsider, Rinkeno, in the Australian

64. Ibid.

65. Ibid.

66. Author's oral interview Merv Maynard at Newcastle, 1996.

67. Howe 1983, p. 7 .

68. Author's oral interview Merv Maynard at Newcastle, 1996. 
Jockey Club Epsom Handicap. ${ }^{69}$ Hugging the fence all the way, Rinkeno split through an opening and stormed home late, failing to catch the winner Davey Jones by the barest of margins in a photo finish. These disappointments were overshadowed by the fact that young Merv had come to the notice of many of the big time trainers. They now clamoured for the young Newcastle rider who was hailed as the 'Darby Munro of the bush' and 'Tinson's Goldmine'. ${ }^{70}$ It is a measure of the success that Merv Maynard generated through this period, that it was not until the advent of Wayne Harris in the late 1970 s that another northern apprentice was so sought after by the big stables for the major feature races of the Australian racing calendar. This a big statement when other top Newcastle apprentices during those intervening years included John Wade and Robert Thompson. However there is little argument when you consider that before he was 21, Merv in 1951, 1952 and 1953 had ridden in three successive Caulfield cups. He had also ridden in the Epsom, Metropolitan, Doncaster, Doomben 10,000, Doomben Cup, Mackinnon Stakes and the dream of every jockey, the Melbourne Cup. The 1952 Melbourne Cup saw the sensational Dalray justly win the event. Yet Merv had a great thrill in piloting three year old Ocean Spray for leading Sydney trainer Danny Lewis into eleventh placing behind the New Zealand champion. Ocean Spray had been well supported and was backed to win over $£ 50,000(\$ 100,000)$ in the Flemington two miler. ${ }^{71}$

Merv Maynard achieved a wonderful victory in 1952 that was to have repercussions 41 years later. He rode Sydney trainer Norman Dewsbury's horse Salamanca in the first Queen's Cup at Randwick on 11 October 1952. ${ }^{72}$ The race in former years had been known as the King's Cup in celebration of the reigning monarch. In fact that was to be the case for this event as well. The race's history dated back to 1927 when the Duke (later King George VI) and Duchess (later Queen Elizabeth, the Queen Mother) of York visited Australia to open Parliament House. During their visit they attended several race meetings. To commemorate the royal visit the Duke's father, King George V, decided he would donate an annual trophy for a horse race in Australia. 'The principle clubs agreed that the race should be a weight-for-age race to be run in rotation around the capital cities... in the years before World War II it was one of Australia's most keenly contested races. ${ }^{.73}$ The quality of the cup can be ascertained by noting some of the winners during this period - Limerick, Valparaiso, Phar Lap and Rogilla to name but a few. In 1952 the young Princess Elizabeth, recently married to Prince Phillip, was en route to Australia on their honeymoon. One of the Princess' engagements in Australia was to attend the running of the King's Cup and present the trophy. In East Africa news reached the young royals that the King had died and they immediately returned to England. Thus the race was renamed the Queen's Cup. ${ }^{74}$

The race itself in 1952 was regarded as nothing more than a contest between the two champions of the period, Hydrogen and Dalray. The other runners appeared to be there for nothing more than to make up the numbers. Merv Maynard had different

69. Howe 1983, p. 7.

70. Ibid., p. 8.

71. Ibid.

72. Bartle 1992, p. 24.

73. Freedman 1990, p. 448.

74. Tbid. 
ideas. Approaching the long Randwick straight he let loose on Salamanca, a tough seasoned stayer carrying a featherweight 7 stones 2 pounds $(45.5 \mathrm{~kg})$, and raced to the front. The move caught the jockeys on the two champions, Keith Nuttall and Darby Munro, by surprise. They had been playing a cat and mouse game with each other. ${ }^{75}$ When Salamanca quickly took the lead from Headstockman and set sail for the post it left them with far too much to do. Dalray made up a lot of late ground but Merv Maynard had pinched the race on the turn. The young rider proudly received the accolades of the crowd at the presentation made by the Governor-General. His only disappointment, one which he was to echo many times over the next four decades, was that only for the King dying he would have met the Princess. ${ }^{76}$

Merv Maynard was now firmly established amongst the elite riders in Australia, riding for trainers like TJ Smith, Danny Lewis, Harry Plant and Vic Thompson. Also riding for high profile owners like flamboyant restaurateur Azzalin 'the Dazzlin' Romano and newspaper magnate Sir Frank Packer. Merv recounts with humour his first meeting with Packer, a man he says who has been the only person who intimidated him with a sense of power. Merv, then only 20, received a call in Newcastle saying that Packer wanted him to ride his horse Top Level in the 1953 Caulfield Cup and that he wanted him to come to his Sydney office for a meeting. Merv was still a shy young man. On arriving at the Daily Telegraph office building in Sydney he did not enter through the front but went to the back where the newspapers were being loaded onto trucks. Asking one of the workmen 'How do I get to Sir Frank Packer's office?' the workmen looked Merv up and down and then pointed to a lift and replied 'See that lift over there boy, well get in that and when it gets to the top that's Sir Frank's office.' Merv followed the instructions. On alighting he found himself in what he describes as the biggest office imaginable with a great shining table endlessly stretching into the distance and only stopped by the imposing figure of the seated Packer. Merv laughs on looking back that if anyone else had been privy to the scene they would have split their sides laughing as Packer was down the other end booming out his instructions on how he wanted his horse ridden. The only part of Merv Maynard visible to Packer was the top of his head from his eyes up, which were peering up over the top of the large table at the distant owner. Merv jokes that even with all of Packer's expert tips and instructions Top Level still ran unplaced in the Caulfield Cup. ${ }^{7}$

It was around this time that he received the first of many lucrative offers to move away from Newcastle. The offer that Maynard jumped at was from the Chinese multimillionaire movie mogul brothers, Run Run and Run Me Shaw. They offered young Merv a lucrative contract to be their stable jockey in. Singapore and Malaya which he readily accepted. He was devastated when his former boss Tinson complained to the Australian Jockey Club and took steps to prevent Merv from accepting the position. Merv was out of his apprenticeship but because he was not 21 years old the Club deemed that he was under the control of Tinson. Merv to this day has the letter that the Australian Jockey Club hierarchy sent him stating that if he attempted to take the position with the Shaw brothers they would not issue him with a jockey's license. This

75. Howe 1983, p. 4.

76. Bartle 1992, p. 24.

77. Author's oral interview Merv Maynard at Newcastle, 1996. 
would have resulted in him not being able to ride. ${ }^{78}$ Subsequently top jockey Athol George Mulley gained the position after Merv had to turn down the offer. Mulley spent three seasons in Asia as the leading rider in a very lucrative environment. Merv, hiding his disappointment, continued successfully on the home front winning the Australian Jockey Club Cannonbury Stakes on the Vic Thompson trained Gulf Palm.

In 1953 Merv began an all too short a relationship with the horse that he regards as far and away the best he ever threw a leg over. Merv reminisced that during the four decades that he rode, on many occasions he would receive calls from different trainers asking him to ride one of their horses, many confided that they had unearthed a champion! Merv received such a call one late night in early may 1953 from a little known young southern district's trainer, Paul Graham. The horse was Alinga! He was a jet black gelding, by Tetreen from Ray's Ornament. He was bred and raced by AJ Maple Brown a wealthy grazier from the Goulburn district. Ray's Ornament was ridden by her owner in the Light Horse Brigade. Maple Brown had Alinga broken in when he was four years old to race at local bush country picnic races. However, in a very short time, it became evident that Alinga was something very special and far too good to just race in country and picnic events. From February 1951 to May 1953 Alinga had contested 31 races and won 29 of them carrying massive weights that today are totally out of the bounds of imagination. He was justly labelled 'the Bernborough of the bush' and he won an endless succession of picnic Cups including, the 1952 Boorowa Cup (10 stones 8 pounds (66.6 kg)), 1952 Goulburn and Merilla Cup (10 stones 11 pounds (67.95 kg)), 1952 Canberra Cup Picnic Rave Club (10 stones 9 pounds $(67.05 \mathrm{~kg}$ )), 1952 Southern Districts Landgrove Cup (10 stones 13 pounds (68.85 kg)), 1953 Crookwell and District Corringle Cup (12 stones 6 pounds (78.3 kg)), 1953 Boorowa Memorial Cup (12 stones 11 pounds $(80.55 \mathrm{~kg})), 1953$ Goulburn Merilla Cup (13 stones 4 pounds $(83.7 \mathrm{~kg})), 1953$ Yass Ravensworth Gold Cup (13 stones 4 pounds $(83.7 \mathrm{~kg})$ ) and the 1953 Canberra Picnic Race Club Cup (13 stones 12 pounds)! Remarkably the day after his victory in the Canberra Picnic Race Club Cup carrying that massive weight of 13 stones 12 pounds or $87.3 \mathrm{~kg}$ Alinga was saddled up to run in the ACT Canberra Cup. He carried 9 stones 10 pounds $(61.2 \mathrm{~kg})$ and toyed with the opposition to win easily by one and a half lengths. It was now evident to all and sundry that Alinga was far too good to be wasted racing around the bush for meagre prize money. ${ }^{79}$

Merv looks back with relish to that day of 6 May 1953 when he was in the Canterbury saddling enclosure receiving his riding instructions from Paul Graham. Merv's first view of Alinga striding into the enclosure is something he will never forget. He says that in 46 years of race riding this was the only time he experienced hairs on his neck literally stand on end by just the look of a horse. Alinga was a magnificent animal, a giant jet black gelding who fairly rippled with muscle and power. Merv remembers confiding to Paul Graham 'If your horse can gallop anything like he looks then you might have a champion' ${ }^{80}$ Alinga's city debut was in the 11 furlongs $(2.2 \mathrm{~km}$ ) Campsie Graduation at Canterbury. ${ }^{81}$ Under the set weight conditions of the event Alinga carried for him what

\footnotetext{
78. Howe 1983, p. 8.

79. Ibid., p. 5.

80. Author's oral interview Merv Maynard at Newcastle, 1996.

81. Bartle 1992, p. 25.
} 
must have seemed like a postage stamp of 8 stones 8 pounds $(54 \mathrm{~kg})$ in comparison to those huge weights he had carried in the bush. The bush champ was elevated to 3 to 1 and second elect in the betting markets for the event behind even money favourite Audacious, who was ridden by Jack Thompson. It was nothing more than an exercise gallop for Alinga who cruised to the post winning by one and a half lengths. ${ }^{82}$ Sydney racing experts were unanimous in their praise of Alinga hailing him as the best horse to come from the country in years.

This initial gloss received a loss of tarnish in Alinga's next three runs. He was beaten by Prince Dakhil in a photo finish in the 11 furlongs $(2.2 \mathrm{~km})$ May Handicap at Warwick Farm. Then the unthinkable, he ran unplaced for the first time in his career in the 10 furlongs $(2.01 \mathrm{~km}$ ) Tattersall's James Barnes Plate at Randwick, again the winner being Prince Dakhil. Nine days later Alinga was back on the track. He was beaten into second place in a photo finish this time by Royal Glitter in the 13 furlong $(2.61 \mathrm{~km})$ Coronation Cup at Randwick. This race was staged by the Australian Jockey Club to commemorate the coronation of Queen Elizabeth II. A fortnight later Alinga was entered at Canterbury in the nine furlongs $(1.81 \mathrm{~km})$ Birthday Handicap. Unlike his last three starts, Alinga received huge betting support and was backed into 5 to 2 favourite. Third on the turn Maynard set Alinga alight and he swept past the leaders like they were standing still, eventually eased down on the line winning by four lengths and clipping a full second off the track record. This win was good enough for Sydney bookmakers to install Alinga as equal favourite with Hydrogen for the upcoming Doomben Cup. Alinga had no luck in Brisbane. He drew the extreme outside barrier of 26 . The bush champ never got on the track and though second at the leger he faded in the run to the line. The winner was French Echo who Alinga had beaten pointlessly at their last meeting in Sydney. Only five days after his Doomben failure the 'iron horse' was saddled up for the Grafton Cup carrying top weight of 9 stones 3 pounds $(58.05 \mathrm{~kg})$. Alinga was driven to victory by Merv Maynard at his vigorous best just pipping by a half head Britavah ridden by renowned country jockey 'Skeeter' Kelly. Close up third, on Ben Hero was another top country rider, Bill Wade. There was still no rest for the hardy Alinga. Only fourteen days later he was back in Sydney where on 1 August 1953 he contested the Sydney Turf Club Cup at Rosehill. Well weighted at only 8 stones 6 pounds $(54 \mathrm{~kg})$, Alinga was immediately made favourite for the 12 furlong $(2.41 \mathrm{~km})$ event. It was another brilliant ride by Merv Maynard as he got the favourite home by a half length from George Mulley's mount Lord Saunders. The winners cheque was $£ 2,436(\$ 4,872)$ with a gold cup valued at $£ 300$ ( $\$ 600)$ pounds. ${ }^{83}$

This victory was instrumental in Alinga being posted as an early favourite for the Caulfield and Melbourne Cups. Alinga was sent back to Goulburn for a short seven week let up. He returned to Sydney where he was entered in the 7 furlongs $(1.4 \mathrm{~km})$ Theo Mark's Quality Handicap at Rosehill. Alinga was beaten for early pace in the event but flashed home most impressively to finish fifth behind Carioca. Alinga's final lead-up race for the Australian Jockey Club Metropolitan Handicap was the 10 furlongs $(2.01 \mathrm{~km})$ Squatters' Handicap on the opening day of the 1953 Randwick Carnival. Alinga again received heavy betting support and was backed into 9 to 4 favourite for the

82. Howe 1983, p. 5.

83. Ibid., p. 6. 
event. Disaster struck. Alinga was just making his move at the leaders when he suddenly faltered. Merv Maynard interviewed after the race said he felt Alinga stumble soon after straightening: 'I was just going around the leaders when Alinga's leg seemed to go on him'. ${ }^{84}$ It was apparent the injury was a serious one. When the horse was led back into the enclosure his young trainer Paul Graham broke down in tears. The horse was in obvious distress but the initial prognosis was that it was most likely torn ligaments in the rear nearside pastern. Alinga was floated back to his Randwick stables where it soon became apparent that Alinga's injury was of a far more serious nature. The horse needed to be physically lifted from the float. Close veterinarian examination revealed that the near fetlock joint had been broken. Thereafter a 16 day battle was waged and every attempt made to save Alinga's life. Efforts were instigated to patch up the shattered leg. Even a last minute appeal by a doctor to allow the horse to recuperate on his property failed and on 19 October 1953 under the direction of the RSPCA Alinga was destroyed. ${ }^{85}$

It was in 1953 that the leading Melbourne stable of the day brought Merv once more to the spotlight when, in the hope of securing one of Australia's best lightweight jockeys, they offered the young Novocastrian what at the time was one of the most fabulous offers ever made to a rider for his services in Australia. Maynard would get a retainer of $£ 1,000$. In addition to this 'grand' Maynard was to receive a $£ 25$ a week living allowance, the use of a car and a percentage of all placed mounts. 'Most jockeys some in even more demand than the Newcastle king of the pigskin would have rushed the offer but not the shy unassuming lad from the coal city ${ }^{86}$ Merv, not wishing to leave Newcastle, refused the offer. Alinga's death saw Merv Maynard step away from metropolitan racing for a while. He took to the country cup circuit where, over the next four decades, he amassed what is most likely the most impressive array of country cup victories ever attained in NSW. The three Muswellbrook, the two Cessnock and Port Macquarie and the Armidale, Lismore, Tamworth, Grafton, Kembla, Scone, Coffs Harbour, Quirindi, Wellington, Aberdeen, Denman, Gulgong, Mudgee, Taree, Parkes, Dubbo and Gulargambone Cups were only some on the Maynard sideboard. ${ }^{87}$ It was not uncommon during those days, especially at his home track of Broadmeadow, to see Merv riding three, four and five winners in a meeting. ${ }^{88}$

In 1958 Merv was finally tempted away from Newcastle when he accepted an offer to ride in New Zealand for trainer Larry Wiggins. ${ }^{89}$ Whilst in New Zealand, Merv rode winners for top New Zealand trainer George Green including the Whangari Cup on Ole. He also rode for the American millionaire owner J De Bloiswack. Merv returned to Newcastle from New Zealand in 1959 and immediately took up where he left off winning races, including the important Newcastle sprint, the Newcastle Jockey Club Newmarket, on Ammanulla. In 1960 he took out his second Newcastle jockey's premiership, a feat he would have had far greater hold over had his services not been so sought

\footnotetext{
84. Ibid.

85. Howe 1983, p. 6 .

86. Goodwin 1953, p. 50.

87. Howe 1983, p. 9.

88. Ibid., p. 8.

89. Ibid., p. 9.
} 
after on metropolitan tracks and at the big carnivals in Sydney, Brisbane and Melbourne. In 1960 Merv attained one of his career ambitions when he won the Newcastle Gold Cup for trainer 'Silent' Leo O'Sullivan with his imported English stallion North Row. O'Sullivan had achieved legendary status as the manager of the tragic boxing champion Les Darcy. Merv Maynard rode one of his great rides to get North Row home in a titanic struggle with second placegetter Vintage. The two horses staged a war overthe concluding stages of the race. North Row gained the judges' verdict by an eyebrow. ${ }^{90}$

The culmination of this victory saw a jubilant Merv accept a position as rider for the leading trainer, Keith Daniels, in Singapore and Malaysia. Merv stayed in Asia for four years. His most important victories were in the Penang Cup on Kerrie Dale and the Sultan's Cup on Kodama. ${ }^{91}$ He rode winners for the Sultan of Jahor and made many lifelong friends, one of whom was Melbourne jockey Ken Smith. One man he rode for was wealthy Chinese tin mine owner WS Lim who took an immediate liking to Merv and his wife Judy. Lim provided them with the pick of any motor vehicles from his garage. Merv laughingly recalls driving around in a Jaguar, Mercedes and a little red MG Sports car. The downside was that Lim was forever at Merv's side for every minute of nearly every day. Not wanting to insult him, Merv and Judy had to tolerate this. One funny highlight of Lim's attraction surfaced when Merv received a request to ride in Kuala Lumpur. Lim was tied down with business commitments in Singapore and apologetically begged Merv's and Judy's forgiveness for not being able to accompany them. He provided a plane none the less and saw Merv and Judy off. Merv and Judy rubbed their hands with glee. At last they had given the adoring Lim the slip. That night in their Kuala Lumpur hotel room the phone rang and Judy answered the call. It was Lim. Judy asked him how the weather was in Singapore. Lim replied 'I not in Singapore'. Judy remarked 'Oh where are you then Lim?'. He replied enthusiastically, 'I in room next door.' He had finished his business commitments early and had arranged a later flight. He said how happy he was to surprise his friends with a late night dinner. Surprise them he did! Judy Maynard has no hesitation in describing Lim as one of the kindest and most genuine human beings she has ever met. Some years later his body was discovered in a Hong Kong hotel room. Sadly after the disintegration of his marriage he had died a lonely man! ${ }^{92}$

In 1964 Merv returned to Australia. The first meeting he attended was in the upper Hunter at Aberdeen. He obligingly booted home a treble of winners. ${ }^{93}$ From this point on race riding took somewhat of a back seat position for Merv. With the connections he and Judy had made in Asia they established a thoroughbred bloodstock agency, selling horses to their contacts. Predominantly they sold to Singapore and Malaysia but over the years they also sold horses to New Caledonia, Macau, Hong Kong and South Korea. Merv began to spend more time tending to their horses and with business trips to Asia, than to race riding, until his involvement with riding was almost a part time occupation. He could not sever his links completely with racing and

\footnotetext{
90. Ibid.

91. Ibid.

92. Author's oral interview Merv Maynard at Newcastle, 1996.

93. Howe 1983, p. 8.
} 
the ensuing years continued to see him ride his share of winners adding all the time to his already impressive tally of feature race victories on country tracks. ${ }^{94}$

In 1981 Merv's riding keenness was rekindled when Judy was granted one of the first trainers permits issued to a woman. Merv and Judy were soon in the winner's list clocking up wins with Patana and Prince Razzo at Muswellbrook and Newcastle. The Maynard combination achieved a historical milestone with the grey gelding No Score. This plugging grey won two races at Randwick racecourse. On the first occasion he was partnered by Jack Thompson when Merv could not make the weight of $49 \mathrm{~kg}$. But in his second victory, No Score was ridden by Merv in the 2,000 m Chester Handicap. ${ }^{95}$

Merv received a setback in 1982 when he was heavily thrown and trampled in the saddling enclosure at Newcastle racecourse. He was badly injured, suffering three broken ribs, a broken collarbone and a punctured lung and spent a week in the intensive care unit of the Newcastle Mater hospital. However Maynard's long career was marked by his professionalism. Always superbly fit and in prime physical condition, even after having turned 50 , he showed the benefit by quickly bouncing back from his injuries and within three months was back riding winners. ${ }^{96}$

At the Newcastle Cup carnival of 1983 Judy and Merv were once more grabbing the headlines. The family combined successfully when Mirror Jack ridden by Merv won the opening event, the Maiden Handicap. Mirror Jack was owned by a group of Melbourne bookmakers and they proceeded to wreck havoc on the Newcastle bookmakers executing a superb and well kept plunge. They backed Mirror Jack in from 25 to 1 to 4 to 1 favourite. Under Merv's guidance and experienced hands Mirror Jack raced to the front at the jump and scooted away in the straight to win easily by two lengths. ${ }^{97}$ Showing no signs of slowing down Merv continued on for the next decade doing what he had always done best, booting home winners. Maybe the numbers were no longer there but each season the name M Maynard continued to go up first on the semaphore boards at racecourses throughout New South Wales.

As stated earlier, the only regret ever expressed by Merv throughout his illustrious riding career had been the missed opportunity to have met the Princess who was later to become Queen Elizabeth II back in 1952 when, as a young 18 year old, he had won the first Queen's Cup. One night in early 1992, Judy Maynard answered a late night call. She was informed that it was the New South Wales Premier's department. They had just received notification from Buckingham Palace that Queen Elizabeth II had expressed the wish on her forthcoming trip to Australia to meet Newcastle jockey Merv Maynard. On her visit to Australia the Queen was to attend the fortieth running of the Queen's Cup and open a new stand at Randwick. She wanted to meet the man who had ridden the first winner of the event. Judy justifiably thought someone was pulling her leg but a further call from Australian Jockey Club Chairman, Bob Charley, confirmed Merv's royal audience. Merv and Judy went to Randwick on 22 February 1992 and before a large crowd, Merv Maynard shook hands with the monarch. ${ }^{98}$ He spent some

94. Ibid.

95. Ibid., p.9.

96. Bartle 1992, p. 25

97. Howe 1983, p. 9.

98. Bartle 1992, p. 24. 
40 minutes talking to the Queen and Prince Phillip, both avid racegoers. Merv even tipped them the winner of the Queen's Cup. Both the Queen and Prince Phillip were impressed that Merv at 60 was still riding and getting up the occasional winner.

Having achieved this lifelong ambition there was now nothing more for Merv to do. On 1 August 1994 at the age of 62 he handed in his rider's licence after 46 years of race riding. Although he gave up race riding, Merv did not cease riding trackwork and in late 1998 he is still to be found, each morning at Broadmeadow racecourse riding a couple the same as he has done for the past 50 years. Merv Maynard was considered as one of the top Australian riders in a period regarded as the golden age of Australian jockeys. He rode against all the greats like Darby Munro, Billy Cook, Jack Thompson, Neville Sellwood, George Moore, Athol Mulley, Scobie Breasly, Bill Williamson and Lester Piggott and, in later years, generations of new top riders like Ron Quinton, Peter Cook, Kevin Langby, Malcolm Johnstone and Wayne Harris. Having ridden over 1,500 winners and ridden countless cup victories 'Merv Maynard is one of the legendary horsemen who have graced the pigskin in postwar Australia. There have been few finer ambassadors for the "Sport of Kings"'. 99

\section{Richard Lawrence 'Darby' McCarthy}

Richard Laurence McCarthy was born in 1943 at Cunnamulla, Queensland. ${ }^{100}$ The son of an Aboriginal stockman, he was the eighth child in a family of 12, six boys and six girls. He gained an early horseback education riding brumbies on a Cunnamulla station. At the age of nine, to help support his large family, he went to work at Yakara station about $50 \mathrm{~km}$ south west of Thargomindah. ${ }^{101}$ Yakara was owned by Charlie Easton, a keen racing man. ${ }^{102}$ With his mother, five brothers and six sisters young McCarthy lived in a tent on the property. His job was to round up horses for the stockmen before the start of each working day. ${ }^{103}$ McCarthy displayed a natural talent on horseback, his balance and skill evident to those who saw him in the saddle. He could ride wild calves and brumbies as well as any of the senior riders. When he was 12 , Darby was taken to a small picnic race meeting at Thargomindah by his father and Charlie Easton. McCarthy recalls the day: 'I was given the ride on Rusty in a five furlongs sprint he jumped straight as a gun barrel at the start and led all the way. ${ }^{104}$ His winning ride impressed an enthusiastic Easton who nicknamed him 'Darby' after the famed jockey Darby Munro. The nickname stuck and in later years was a fitting accolade for a rider who would scale dizzying heights as a jockey. ${ }^{105}$

Darby McCarthy would prove to be one of the most naturally gifted riders ever to grace the Australian turf. Sadly, McCarthy's time at the top would prove to be only fleeting as his career stumbled with stops and starts plagued by controversy and personal problems. McCarthy could be compared to soccer's Irish wizard, George Best, as a gifted genius prone to bouts of erratic and unpredictable behaviour and to falling foul

\footnotetext{
99. Howe 1983, p. 9.

100. Weate 1966, p. 44.

101. Dawson 1990, p. 18.

102. Weate 1966 , p. 44.

103. Dawson 1990, p. 18.

104. Weate 1966 , p. 44.

105. Ibid.
} 
of officialdom. Darby, like Best, was his own worst enemy yet blessed with a talent so rich it could only be termed 'God given'. He was not without advisers. Darby's eldest brother, Ted, had built up a reputation as a good jockey especially in the Toowoomba area until weight problems curtailed his career. Darby also befriended leading amateur rider Noel Thompson. In 1958 whilst in Brisbane visiting his sick father, young Darby attended the race meeting at Albion Park. He was standing watching the horses parade in the saddling enclosure where he was noticed by a well known trainer, Ted Hennessy. Hennessy was not slow in coming forward and having noticed young Darby's interest immediately asked him if he was in need of a job. The gleam in Darby's eyes was all the confirmation Hennessey required so Darby became apprenticed in October 1958. Ted Hennessey had stables at Hendra. He gave the young Darby his chance. At only his third professional ride Darby was victorious at Kilcoy. ${ }^{106}$

McCarthy's climb to the top of racing was under way. He rode his first city winner at Doomben on the 50 to 1 chance Rio Sand ${ }^{107}$ In 1960 Darby was.dux of the Queensland Turf Club's Apprentice School. He was presented with a saddle by the Governor of Queensland, Sir Abel Smith. ${ }^{108}$ Around this time a newspaper reader complained of a reporter's continual reference to Darby being Aboriginal. Darby, aged only 17, laconically replied:

I think the man is sincere and trying to be fair but he misses the whole point. If any newspaperman wants to do me a favour he can call me an Aborigine as often as he mentions my name-because that is what I am and if $I$ am going to be a success it is important that $I$ be known as an Aboriginal success. ${ }^{109}$

In his first three years in the saddle Darby chalked up over 100 winners with wins in Queensland, New South Wales and Victoria. Feature races were not long in coming to the talented rider. He won the 1960 Brisbane Summer Cup on Midswain and the 1960 Brisbane Tattersalls Cup on Melbourne galloper Dow Street. He journeyed to Melbourne in 1961 for the spring carnival where he partnered Dow Street in Australia's premier race, the Melboume Cup. He was unscathed when Dow Street fell in the big two miler. Darby was now spending a lot of time riding at important meetings in New South Wales. He was victorious on the Mal Barnes trained Alspick in the six furlongs $(1.2 \mathrm{~km})$ Ramornie Handicap at Grafton. Alspick was by Avignon out of Estana. He was sold as a yearling in 1957 for 125 guineas by the Melton Park Stud owners, former champion jockeys Edgar Britt and Harold James. In 1962 whilst still an apprentice, Darby came south. He partnered Tamure to win the Newcastle Gold Cup for Warwick Farm trainer Norman Turnbull. Darby's association with Alspick now hit a purple patch. In December 1962 they combined to win the Australian Jockey Club Summer Cup by eight lengths. Darby rode a great race hugging the fence. He was never worse than fifth and Alspick was steered through needle eye openings to race away with the event. They backed up on New Year's Day 1963 to win the Tattersall's Club Cup. Darby then formed a strong association with the Bobby Sinclair trained Mullala. On his first six rides on the horse, Darby recorded five wins including a brilliant victory in the $\$ 20,000$

\footnotetext{
106. Ibid.

107. Tbid.

108. Tbid., p. 45.

109. Tatz 1987, p. 58
} 
Stradbroke Handicap. ${ }^{110}$ With his apprenticeship coming to a close and his services so sought after in the south, Darby transferred to Norman Turnbull's Warwick Farm stables. ${ }^{111}$ Darby returned home to Queensland in 1964, now a fully fledged jockey. He repeated his previous year's victory by guiding Cele's Image to victory in the Stradbroke. ${ }^{112}$ The year 1965 saw more important victories come the way of Darby McCarthy. He rode Patient Polly to victory in the Grafton Cup and won the Canterbury Cup on Rakia. He took out the rich Brisbane double in 1966 when he partnered Castanea to victory in yet another Stradbroke and then scored a great victory on Apa in the Brisbane Cup. Darby went into celebration mode and went out and bought himself a diamond tie pin and cuff link set worth $\$ 5,000 .^{113}$

Darby decided to see the world and Europe was his first port of call. The press back in Australia had a field day as they kept the public informed of the whereabouts of 'Dapper' Darby McCarthy. It was reported that he arrived at the races at Royal Ascot in a Rolls Royce complete with top hat and tails. ${ }^{114} \mathrm{He}$ was going to parties with Mia Farrow and Frank Sinatra and got drunk with Lee Marvin and Rock Hudson. ${ }^{115}$ Darby decided to set up base in France. He was besieged with contract offers. He finally. accepted an offer from a top French trainer, Maurice Zilber, who trained for the international art entrepreneur, Daniel Wildenstein. The contract was lucrative to say the least, including a retainer, bonuses for prizemoney won, a car and lavish home in Chantilly complete with a French maid. This was a world far removed from living in a tent on Yakara station. The boy from the bush had arrived as he wore $\$ 400$ pale blue suits to the races. ${ }^{116}$ Darby rode for owners like the Rothschilds and Prince Aly Khan. ${ }^{117}$ He rode in races in France, Germany, England and Ireland during his European stay.

Homesickness in 1968 prompted the return of Darby McCarthy to Australia and he took out the 1968 Doomben 100,000 on Gay Gauntlet. In one golden afternoon at Randwick in 1969 at the Australian Jockey Club Carnival he annexed the two premier events, taking out the Australian Jockey Club Derby on Divide and Rule and then, in the very next race, he rode Brokers Tip to an exhilarating victory in the Australian Jockey Club Epsom Handicap. Darby had scaled the heights of his profession. His ride on Divide and Rule was recorded as:

the horse was ridden a treat by McCarthy. So beautifully was he placed throughout by the 25 year old Aboriginal that many excuses came from many quarters in that they met with setbacks while the winner enjoyed a travel free passage throughout the race. ${ }^{118}$

The excuses were pretty lame, however, because Darby and Divide and Rule had coasted to the line some five lengths clear of the field. The victory on Brokers Tip in the Epsom was even more impressive. Trapped in a tight pocket for more than two and a half fur-

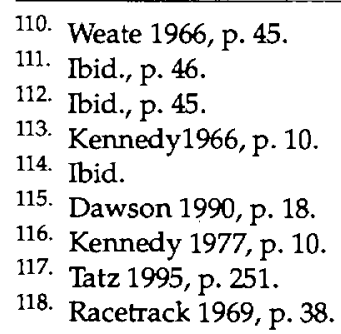


longs Darby forced a passage, hooking out from behind four runners to charge down the outside and snatch victory from the Roy Higgins' ridden Alrello. ${ }^{119}$

The fairytale had reached its zenith that afternoon at Randwick. From there it began to form into something more akin to a nightmare as Darby's career hit a spiral rollercoaster descent. In an interview in 1984 he recalled: 'I've been right up on top and I've been way down there at the bottom. And, baby, believe me, it's a lot better being up. ${ }^{120}$ Darby was a man who had drank champagne with aristocracy and at one time owned 20 French tailor made suits. ${ }^{121}$ That flash lifestyle was beginning to have an adverse affect on his career. It now took a nosedive.

McCarthy's drop from the top accelerated further in the mid 1970s when Victorian stewards disqualified him for seven years for allegedly conspiring to 'fix' a race at a lowly midweek meeting at Hamilton in Western Victoria. ${ }^{122}$ On 30 March 1976 he was mentioned in the stewards' report. It stated that his mount had interfered with the beaten favourite. On 18 June, the Hamilton racing club charged Darby and the trainer, Bob Smeardon, with a number of offences. The investigation had been instigated by the trainer of the beaten favourite, George Rantall, who alleged that he had been approached to 'slow' the favourite. An unnamed individual who failed to appear before the inquiry was also charged. The inquiry went into its eleventh hearing and the stewards spent over six hours deliberating about the accusations and the evidence. ${ }^{123}$ They announced that Darby McCarthy was disqualified for seven years. Smeardon was to relinquish his trainer's licence. The unnamed person was warned off racecourses for life. Darby strongly denied any wrong doing and pleaded his innocence from any plot, but it all fell on deaf ears. There is nothing worse for a jockey to contend with than the stain of wrong doing. Darby fought to clear his name. He lodged an appeal with the South Western District Racing Association and, largely with the help of a group of top lawyers including a later Victorian Premier, John Cain, and Victorian State Ombudsman, Sir John Dillon, his penalty was reduced to two years. But Darby never gave up the fight to prove his innocence. Further appeals were instigated and eventually the disqualification was dropped and all reference to the matter was to be removed from Darby's record.

Darby recalled filling in the form for his return to race riding: 'when I asked whether I should put in the disqualification when I went to get another licence they said no, it had been removed. There was no disqualification.' Darby could not believe it: '...Well if I haven't been disqualified, where is my house, my money and why hadn't I been able to make a living from racing for 10 months?'124

Insurmountable damage had been done. The calls for rides were no longer there and the backslappers only to pleased to associate with a winner were now no longer to be found. The episode had ruined Darby's marriage. He had begun to drink. He recalled: 'It wasn't a good time for me.' ${ }^{\prime 25}$ To make matters worse Darby had continued

119. Ibid., P. 42.

120. Owen 1984, p 54.

121. Penton 1987, p. 236.

122. Owen 1984, p. 54.

123. Kennedy 1977, p. 11.

124. Dawson 1990, p. 19. 
to spend in the fashion he had been accustomed to. Soon the money was all gone. Before it had been so simple. He would ride a few winners, fill his pockets with money and go out and buy cars and houses. He recalled: 'When I ran out I would do it all over again'. ${ }^{126}$ Times were now so different. There was no easy way to replenish the coffers. He started selling off his property to get money, even his much valued tie pin and cufflinks which fetched only $\$ 1,250$. Darby found himself at odds with the police. He recalls the nightmare: 'I'd have a drink and I'd be a zombie, talking duck talk. People would see me and reckon I was on the grog heavy. ${ }^{127}$ Darby was faced with every jockey's dread, increasing weight troubles. He declared: 'drink was never the main problem. It was other things that got me. A friend put me on prescription drugs which I swallowed like smarties to keep my weight down. ${ }^{128}$ Darby says, frankly: 'In those days we were never warned of the dangers of mixing those kinds of drugs with drink. ${ }^{129}$ He discovered the body of his young brother dead after an overdose of the prescription drugs. ${ }^{130}$ An attempted comeback with Victorian master trainer of two year olds, Cliff Fahler, came to a crashing end. Darby, still walking the tightrope of weight reduction drug taking, had put his arm through a plate glass window. It was nearly severed. The arm was saved but with restricted movement in the left wrist. Under enormous strain Darby buckled under the weight of his decline. 'He was admitted to a psychiatric ward for evaluation. He was discharged on his own cognisance but voluntarily booked himself into a drug and alcohol rehabilitation centre. ${ }^{131}$ Darby dried out and began the slow climb back out of his own personal hell. He overcame obstacles over his weak arm to once more gain a rider's licence. In 1978 he made his comeback, this time in New Caledonia. He returned to Sydney and renewed his long time association with Mal Barnes. He seemed to be back on track. He and Barnes combined to take out the 1978 Tancred Stakes with Hyperno. But it was only a short lived return. Darby recalled: 'I wasted hard and got my weight down to 54.5 kilos but I wasn't getting any rides. It didn't seem worth it. I couldn't do it any more.' 132

Darby remarried and packed up and headed back to Queensiand to begin a new life as a trainer. With the backing of his old friend, Lloyd Foyster, he set up a training centre at Toowoomba's Clifford Park course. On 18 February 1984 he won his first race as a trainer when the 15 to 1 shot Ptah was first past the post. ${ }^{133}$ He started out with 14 boxes and, with further additions from the Foyster string, life looked rosy for Darby. Yet he was not content. He approached the Federal Government through the Department of Aboriginal Affairs with the outline of a plan to set up a scheme where he could take in young Aboriginal kids and teach them the art of horsemanship. His brief stated that after his expert tuition these boys would be well placed to go out into the razor edge world of racing, equipped both mentally and physically to face the perils of big time

\footnotetext{
125. Owen 1984, p. 55.

126. Dawson 1990 , p. 19.

127. Kennedy 1977, p. 11.

128. Ibid.

129. Tbid.

130. Ibid.

131. Dawson 1990, p. 19.

132. Owen 1984, p. 55.

133. Ibid,, p. 54.
} 
racing. Not only that, McCarthy wanted to see young Aboriginal kids gain an opportunity like he had gained. ${ }^{134}$ Darby said:

This is something I've always wanted to do. I've built up a lot of knowledge and I want to pass it on. I keep thinking how many other young black kids would have made something of their lives if they had been able to do this sort of thin. ${ }^{135}$

The Department thought the plan a good one and gave it the necessary support to set it up. Darby was enthusiastic about its operation. He would have boys in his care for some 13 weeks. During that time the boys would receive tuition on every aspect of life in and around a racing stable including learning to ride, mucking out stables, grooming, shoeing, feeding and every conceivable aspect of horse care. Darby was firm with the boys. He said they also needed to learn to do what they were told. He took them to the track each morning and attended race meetings. They were shown race videos which they then discussed. Two apprentices, Courtney Appo, and Darby's nephew, David McCarthy, came through the instruction and were immediately able to secure apprenticeships. ${ }^{136}$ Sadly after some three years of operation the apprentice school was disbanded. Darby was disillusioned with the lack of drive and commitment on the part of many of the boys. ${ }^{137} \mathrm{He}$ also found the life of a trainer having to deal with owners a far more cutthroat world than that of a top jockey. He continued living on in the Toowoomba area and, in 1987, he unsuccessfully stood as the Australian Democrat candidate for the seat of Maranoa in the General election. ${ }^{138}$

In mid-1990 at the age of 45, Darby McCarthy initiated one more attempt at a comeback as a jockey. On Friday 28 July 1990 Darby was re-licensed by the Queensland Turf Club Committee. When given the news Darby was elated. The very next day saw him return to race riding at Brisbane's Doomben race course. His mount finished unplaced but Darby was nevertheless ecstatic. He remarked: 'It's hard turning your life around after 10 years but the old touch is still there and I want to ride. ${ }^{139}$ Despite Darby's enthusiasm and commitment to the task, the stark realities soon came to the fore. Although the heart was willing the body was no longer up to the task. Darby once more and for the last time pulled up the shingles on what was a remarkable career.

The accolades for Darby McCarthy's skill in the saddle are numerous. Colin Tatz has highlighted a few. Bert Lillye described: 'a marvellous pair of hands... a genius rider. No jockey was riding better in 1968 and 1969. He had a natural talent. He never worked at his riding as did George Moore.' Tom Brassel said: 'he is one of the finest jockeys I have ever seen-he was consistently good; a quite man, he was a thorough gentleman'. 'A very gifted rider' thought Pat Murray. George Moore's final words simply described Darby as 'a freak'. ${ }^{140}$ For an all too brief a time, like that spring Saturday afternoon at Randwick when he won the Derby and the Epsom, Darby McCarthy had

134. Penton 1987 , p. 282.

135. Owen 1984, p. 55.

136. Tbid.

137. Dawson 1990, p. 19.

138. Tatz 1995, p. 250.

139. Dawson 1990, p. 19.

140. Tatz 1995, p. 250. 
scaled the mountain of his profession. In the Sport of Kings at that time he was King of the World.

Peter St Albans, Merv Maynard and Darby McCarthy can be held high as beacons of Aboriginal achievement in a very intense, competitive and physically demanding sport. They achieved untold success across some of Australian racing's most exciting decades. They mixed it with the best of their profession, playing their part in the sheer exhilaration and excitement of Australian racing. Their stories vividly display them playing an active role through the pages of some of racing's most colourful and famous history.

John Maynard is indigenous research academic lecturer with the Umulliko Centre at the University of Newcastle. In 1996 he was Stanner Fellow at the Australian National University, this fellowship awarded every second year to one indigenous scholar. He has held other research and teaching positions at the two universities.

\section{References}

Ahern, W. 1982, A Century of Winners, Brisbane.

Arnold, T. 1969, Racetrack(December), Sydney.

Baldwin, S. 1988, 200 Unsung Heroes and Heroines of Australia, Victoria.

Bartle, J. 1992, Turf Monthly (May), Wentworth Falls.

Broome, R. 1982, Aboriginal Australians, Sydney.

Cavanough, M. 1983, The Melbourne Cup 1861-1982, Victoria.

1976, The Caulfield Cup, Parramatta.

Clouten, K.H. 1967, Reid's Mistake, Adelaide.

Dawson, G. 1990, Turf Monthly (October), Wentworth Falls, NSW.

Freedman, H \& Lemon, A 1990, The History of Australian Thoroughbred Racing, vol. 2, Victoria.

Gadfly Media 1996, Legends of the Racetrack, Alexandria, NSW.

Goodall, H. 1996, Invasion to Embassy, St Leonards, NSW.

Goodwin, K: 1953, Sports Novels (August), NSW.

Hickie, D. 1986, Gentlemen of the Australian Turf. North Ryde. NSW.

Horner, J. 1994, Bill Ferguson: Fighter for Aboriginal Freedom, Canberra.

Howe, R. 1983, Turf Monthly (February), Wentworth Falls, NSW.

Kennedy, R 1977, Racetrack (June), Manly, NSW.

Miller, M. 1985, Report of the Committee of Review into Aboriginal employment and training programs, Canberra.

Owen, P. 1984, Racetrack (June), Pyrmont, NSW.

Penton, N. 1987, A Racing Heart, the Story of the Australian Turf, Sydney.

Pollard, J. 1981, The Pictorial History of the Australian Turf, Sydney.

— 1988, Australian Horse Racing, Sydney.

Reynolds, H. 1990, The Other Side of the Frontier, Ringwood, Victoria.

1990, With the White People, Ringwood, Victoria. 
Tatz, C. 1987, Aborigines in Sport, Bedford Park, SA.

_- 1995, Obstacle Race: Aborigines in Sport, Sydney.

1996, Black Diamonds, St Leonards, NSW.

Weate, W. 1966, Racetrack (June), Sydney. 